\title{
Study on the Correlation between Salivary pH and the Use of Mouthrinses in Young Adults
}

\begin{abstract}
LIVIA BOBU, ROXANA VASLUIANU*, ELENA RALUCA BACIU, BOGDAN BULANCEA, ALICE MURARIU
Grigore T. Popa University of Medicine and Pharmacy, Faculty of Dental Medicine, 16 Universitatii Str., 700115, Iasi, Romania

The aim of the present study was to assess the correlation between salivary (flow rate, $\mathrm{pH}$ ) and clinical ( $\mathrm{Gl}$, PI) parameters and the use of two common mouthrinses in young adults. A total of ninety subjects were randomly assigned to three groups, i.e. group A -ListerineO, group B $-0.05 \%$ sodium fluoride, and group C distilled water. After 6 weeks of using the corresponding mouthrinses twice a day, the results showed that ListerineO produced the highest increase of the salivary $\mathrm{pH}(7.58 \pm 0.043)$ and flow rate $(0.82 \pm 0.280)$ and the highest decrease of the GI $(0.79 \pm 0.177)$ and $P I(1.30 \pm 0.375)$. Significant correlations $(p<0.05)$ were found between the use of mouthrinses and the salivary and clinical parameters examined.
\end{abstract}

Keywords: saliva, $\mathrm{pH}$, Listerine, fluoride

Salivary parameters (flow rate, $\mathrm{pH}$ and buffering capacity) exert a profound influence on caries risk status and gingivitis. Reduced salivary flow rates result in reduced salivary $\mathrm{pH}$ and buffer capacity, whilst stimulation of salivary flow results in greatly inhanced levels of bicarbonate, which increases the $\mathrm{pH}$ and buffering capacity of the saliva. At the same time, there is an increase in urea with salivary flow, providing the production of basic molecules and counteracting dietary and plaque acids [ 1 , 2].

The average intra-oral $p \mathrm{H}$ is around 7.4 and it slightly decreases during sleep time. The critical $\mathrm{pH}$ is defined as the highest $\mathrm{pH}$ at which there is equal ion exchange between a solid immersed in its saturated solution. The critical $p H$ of dental caries is well established to be in the range of 5.5-5.7, in which $\mathrm{pH}$ levels below this threshold will initiate the dissolution of enamel [3-5].

In conjunction with mechanical hygiene, mouthrinses may aid in controlling supragingival plaque and gingivitis. A mouthwash may be recommended to treat infection, reduce inflammation, relieve pain, reduce halitosis or to deliver fluoride locally for caries prevention [6].

Fluoride is an established antimicrobial agent. Sodium fluoride is regarded as a gold standard of caries prevention. It is extensively used to prevent and treat dental caries due to its anticariogenic and remineralization properties [7].

The efficiency of Listerine ${ }^{\circledR}$ as an oral antiseptic is based on a formula of four essential oils: thymol $0.064 \%$, eucalyptol $0.092 \%$, methyl salicylate $0.060 \%$ and menthol $0.042 \%$. This essential oil penetrates oral microbial biofilm and kills microorganisms by disrupting their cell wall and by inhibiting their enzyme activity. This reduces bacterial load, slows plaque maturation and decreases plaque mass and pathogenicity [8].

The aim of the present study was to assess the correlation between salivary (flow rate, $\mathrm{pH}$ ) and clinical (GI, PI) parameters and the use of two common mouthrinses: $0.05 \%$ sodium fluoride and Listerine ${ }^{\circledR}$ in young adults.

\section{Experimental part \\ Study population}

A randomized blinded controlled trial was conducted on 90 students (50 female and 40 male) attending the Faculty of Dental Medicine of the Grigore T. Popa University of Medicine and Pharmacy in lasi, Romania. The inclusion criteria for the study were: adults with no systemic diseases, having full complement of the teeth, noncompromised oral health (brushed their teeth twice a day), no history of systemic antibiotic use or topical fluoride treatment within 4 weeks prior to baseline, and not wearing any fixed or removable prosthesis or orthodontic appliance. The exclusion criteria were: subjects who wore fixed or removable orthodontic appliances or prosthesis, had been prescribed antibiotics or other antimicrobial medications in the last 4 weeks, had undergone periodontal treatmentin the previous 6 months, having any systemic illness or pregnancy.

Informed consent was obtained from the subjects prior to the study. Data privacy as well as the impossible identification of subjects in the case the results are published were ensured [9].

Clinical examinations were performed by 3 calibrated dentists. The Kappa index had values ranging between 0.78 and 0.83 .

\section{Mouthrinses used and saliva collection}

Commercially available ListerineÒ mouthwash (J ohnson \& J ohnson) and commercially available $0.05 \%$ sodium fluoride mouthwash (Oral-B Pro-Expert) were used as experimental solutions. Distilled water was used in the control group. The mouthwashes were bottled and coded in similar containers $(250 \mathrm{~mL})$. The subjects were randomly assigned to three groups, i.e. group A -ListerineO, group B $-0.05 \%$ sodium fluoride, and group C -distilled water, with 30 subjects in each group.

Sufficient amount of mouthrinse was provided for the six- week period of the study and each subject was given detailed instruction in its use. The subjects were asked to continue with their normal oral hygiene procedures but, in addition, to rinse their mouth after brushing at morning and night, with $20 \mathrm{ml}$ of the mouth rinse containing ListerineO, $0.05 \%$ sodium fluoride or distilled water, for 30 $\mathrm{s}$, twice a day, for 6 weeks. After each application, they were requested not to eat or drink for $1 \mathrm{~h}$. After 6 weeks of regular application, the participants were instructed to stop using mouth rinses. The participants were given the same tooth brush and fluoride tooth paste to brush their teeth twice a day during the study. Before starting the first phase, professional oral hygiene, which included scaling and root 
planing with polishing, was done and the plaque score was brought to zero.

Before saliva collection, patients were kept seated for 5 min, relaxed and without talking. Unstimulated saliva was collected over a period of $5 \mathrm{~min}$. Before collection, the mouth was emptied by an initial swallow. The examinator asked the subjects to spit out the produced saliva each 60 s in a plastic container. Salivary $\mathrm{pH}$ analysis was performed using the chair side kit M-S Saliva Check Buffer Kit (GC America Inc.). Unstimulated saliva was collected and the $\mathrm{pH}$ test paper was dipped in the sample for 10 seconds, then the color changes were compared with the chart provided by the manufacturer and the values were recorded.

\section{Clinical examinations}

Data were collected at baseline, immediately after the first rinse, and every week until the 6th week of study. The subjects were assessed for salivary flow (unstimulated) and $\mathrm{pH}$, as well as for gingival status using the $\mathrm{GI}$ [10] and bacterial plaque using the Quigley-Hein Index [11]. Materials used for the clinical examinations were mouth mirror, periodontal probe and disclosing solution (Mira-2Tone).

\section{Statistical analysis}

Data were statistically analyzed using the SPSS (Statistical Pakage for Social Sciences) 17.0. ANOVA tests were used to identify significant differences between the means of the study groups. Paired t-tests were used to assess the significance of changes within each group between time periods. Correlations were analyzed with the Spearman coefficient. Critical $p$ values of significance were set at 0.05 and a confidence of $95 \%$.

\section{Results and discussions}

A total of ninety subjects of age range 20 to 24 years were recruited into the study and none was excluded throughout the 6 weeks period of evaluation.

Table 1 shows the values of the salivary $\mathrm{pH}$ (mean \pm SD) in the three groups at baseline (before rinsing) and at each time interval of the study. No statistical difference was observed between the three groups at baseline. The evaluation performed 1 minute after the first rinse showed an increase of the salivary $\mathrm{pH}$, statistically significant in groups $\mathrm{A}(p \mathrm{H}=7.93)$ and $\mathrm{B}(\mathrm{pH}=7.83)(p=0.010$ and $p=0.030$, respectively) and non-significant in group $C$ $(p H=6.80 ; p=0.907)$. In groups $A$ and $B$ the $p H$ remained higher than in the baseline examination until the end of the study, with a small decrease in the follow-up examinations; at the same time, the values were significantly higher than in group C $(p<0.05)$, with the highest values for group $A$.

The values of unstimulated salivary flow rate are shown in table 2 . The highest increase was observed in group A, 1 minute after the first rinse: $1.02 \mathrm{~mL} / \mathrm{min}$, as compared to $0.78 \mathrm{~mL} / \mathrm{min}$ in group $B$ and $0.52 \mathrm{~mL} / \mathrm{min}$ in group C; after that, the flow rate decreased slightly at the follow-up examinations, but still remained at the highest value in group A $(0.82 \mathrm{~mL} / \mathrm{min}$ at the 6 -weeks examination) and significantly higher than at the baseline examination $(p<0.05)$. In group $B$ the flow rate increased during the study $(0.52 \mathrm{~mL} / \mathrm{min}$ at the baseline examination and 0.70 $\mathrm{mL} / \mathrm{min}$ at the 6-weeks examination), but the increase was not statistically significant ( $p>0.05)$. No increase was seen in group $C$. Inter-group comparison showed statistically significant differences $(p<0.05)$.

Table 1

DISTRIBUTION AND COMPARISON OF SALIVARY pH VALUES (MEAN \pm SD) IN THE THREE GROUPS

\begin{tabular}{|c|c|c|c|c|c|c|}
\hline Time & Group A & Group B & Group C & F value & $p$ value & Inference \\
\hline Baseline & $\begin{array}{c}6.60 \\
(0.033)\end{array}$ & $\begin{array}{c}6.63 \\
(0.031)\end{array}$ & $\begin{array}{c}6.65 \\
(0.035)\end{array}$ & 0.428 & 0.973 & NS \\
\hline 1 min. & $\begin{array}{c}7.93 \\
(0.058)\end{array}$ & $\begin{array}{c}7.83 \\
(0.029)\end{array}$ & $\begin{array}{c}6.80 \\
(0.060)\end{array}$ & 7.382 & 0.002 & $\mathrm{~S}$ \\
\hline 60 min & $\begin{array}{c}7.82 \\
(0.051)\end{array}$ & $\begin{array}{c}7.76 \\
(0.049)\end{array}$ & $\begin{array}{c}6.73 \\
(0.087)\end{array}$ & 7.211 & 0.003 & $\mathrm{~S}$ \\
\hline 3 weeks & $\begin{array}{c}7.56 \\
(0.048)\end{array}$ & $\begin{array}{c}7.47 \\
(0.046)\end{array}$ & $\begin{array}{c}6.70 \\
(0.053)\end{array}$ & 5.281 & 0.009 & $\mathrm{~S}$ \\
\hline 6 weeks & $\begin{array}{c}7.58 \\
(0.043)\end{array}$ & $\begin{array}{c}7.46 \\
(0.039)\end{array}$ & $\begin{array}{c}6.70 \\
(0.041)\end{array}$ & 5.235 & 0.009 & $\mathrm{~S}$ \\
\hline \multirow{2}{*}{$\mathrm{t}$ test } & $p=0.010$ & $\begin{array}{c}p=0.030 \\
\mathrm{~S}\end{array}$ & $\begin{array}{c}p=0.907 \\
\mathrm{NS}\end{array}$ & & & \\
\hline
\end{tabular}

NS=Non-significant; $\mathrm{S}=$ Significant

Table 2

DISTRIBUTION AND COMPARISON OF SALIVARY FLOW RATE $(\mathrm{mL} / \mathrm{min})$ IN THE THREE GROUPS (MEAN \pm SD)

\begin{tabular}{|c|c|c|c|c|c|c|}
\hline Time & Group A & Group B & Group C & F value & $p$ value & Inference \\
\hline Baseline & $\begin{array}{c}0.51 \\
(0.153)\end{array}$ & $\begin{array}{c}0.52 \\
(0.124)\end{array}$ & $\begin{array}{c}0.51 \\
(0.116)\end{array}$ & 0.395 & 0.992 & NS \\
\hline 1 min & $\begin{array}{c}1.02 \\
(0.212)\end{array}$ & $\begin{array}{c}0.78 \\
(0.325)\end{array}$ & $\begin{array}{c}0.52 \\
(0.213)\end{array}$ & 6.352 & 0.005 & $\mathrm{~S}$ \\
\hline $60 \mathrm{~min}$ & $\begin{array}{c}0.91 \\
(0.175)\end{array}$ & $\begin{array}{c}0.73 \\
(0.521)\end{array}$ & $\begin{array}{c}0.52 \\
(0.214)\end{array}$ & 5.418 & 0.008 & $\mathrm{~S}$ \\
\hline 3 weeks & $\begin{array}{c}0.81 \\
(0.182)\end{array}$ & $\begin{array}{c}0.71 \\
(0.312)\end{array}$ & $\begin{array}{c}0.51 \\
(0.183)\end{array}$ & 4.315 & 0.014 & $\mathrm{~S}$ \\
\hline 6 weeks & $\begin{array}{c}0.82 \\
(0.280)\end{array}$ & $\begin{array}{c}0.70 \\
(0.240)\end{array}$ & $\begin{array}{c}0.52 \\
(0.170)\end{array}$ & 4.728 & 0.012 & $\mathrm{~S}$ \\
\hline \multirow{2}{*}{$\mathrm{t}$ test } & $\begin{array}{c}p=0.043 \\
\mathrm{~S}\end{array}$ & $\begin{array}{c}p=0.070 \\
\mathrm{NS}\end{array}$ & $\begin{array}{c}p=0.983 \\
\mathrm{NS}\end{array}$ & & & \\
\hline
\end{tabular}

NS=Non-significant; $\mathrm{S}=$ Significant 
Table 3

MEAN ( \pm SD) VALUES OF THE GINGIVAL INDEX (GI) IN THE THREE GROUPS

\begin{tabular}{|c|c|c|c|c|c|c|}
\hline Time & Group A & Group B & Group C & F value & $p$ value & Inference \\
\hline Baseline & $\begin{array}{c}1.20 \\
(0.158)\end{array}$ & $\begin{array}{c}1.05 \\
(0.218)\end{array}$ & $\begin{array}{c}1.18 \\
(0.315)\end{array}$ & 0.521 & 0.873 & NS \\
\hline 3 weeks & $\begin{array}{c}0.82 \\
(0.182)\end{array}$ & $\begin{array}{c}0.98 \\
(0.215)\end{array}$ & $\begin{array}{c}1.81 \\
(0.821)\end{array}$ & 9.311 & 0.000 & $\mathrm{~S}$ \\
\hline 6 weeks & $\begin{array}{c}0.79 \\
(0.177)\end{array}$ & $\begin{array}{c}0.96 \\
(0.311)\end{array}$ & $\begin{array}{c}1.92 \\
(0.817)\end{array}$ & 15.283 & 0.000 & $\mathrm{~S}$ \\
\hline t test & $\begin{array}{c}p=0.015 \\
\mathrm{~S}\end{array}$ & $\begin{array}{c}p=0.120 \\
\mathrm{NS}\end{array}$ & & & & \\
\hline
\end{tabular}

Table 4

MEAN ( \pm SD) VALUES OF THE QUIGLEY-HEIN PLAQUE INDEX IN THE THREE GROUPS

\begin{tabular}{|c|c|c|c|c|c|c|}
\hline Time & Group A & Group B & Group C & F value & $p$ value & Inference \\
\hline Baseline & $\begin{array}{c}1.80 \\
(0.471)\end{array}$ & $\begin{array}{c}1.91 \\
(0.516)\end{array}$ & $\begin{array}{c}1.86 \\
(0.482)\end{array}$ & 0.532 & 0.798 & NS \\
\hline \multirow{2}{*}{3 weeks } & $\begin{array}{c}1.36 \\
(0.412)\end{array}$ & $\begin{array}{c}1.62 \\
(0.453)\end{array}$ & $\begin{array}{c}2.18 \\
(0.501)\end{array}$ & 8.225 & 0.001 & $\mathrm{~S}$ \\
\hline \multirow{2}{*}{ 6 weeks } & $\begin{array}{c}1.30 \\
(0.375)\end{array}$ & $\begin{array}{c}1.56 \\
(0.412)\end{array}$ & $\begin{array}{c}2.21 \\
(0.508)\end{array}$ & 14.518 & 0.000 & $\mathrm{~S}$ \\
\hline \multirow{2}{*}{$\mathrm{t}$ test } & $\begin{array}{c}p=0.007 \\
\mathrm{~S}\end{array}$ & $\begin{array}{c}p=0.042 \\
\mathrm{~S}\end{array}$ & & & & \\
\hline
\end{tabular}

The Gingival Index (table 3) was recorded at the baseline examination and then at the 3-weeks and 6-weeks examinations, as no changes were expected 1 minute or 60 minutes after the firstrinse. The only significant decrease was seen in group A $(0.80$ at the 6 -weeks examination, compared to 1.20 at the baseline examination, $p<0.05$ ), meaning a reduction of $34 \%$. In group $B$ the decrease was not significant, and in group $\mathrm{C}$ the $\mathrm{Gl}$ increased during the study. Except the baseline examination, inter-group comparison showed statistically significant differences $(p<0.05)$.

The same time intervals of examination were used for the plaque index, too (table 4). Significant decreases of the Quigley-Hein index were seen in both group $A$ (from 1.80 to $1.30, p=0.007$ ) and group $B$ (from 1.91 to 1.56 , $p=0.042$ ), with the highest reduction of the index in group $A(28 \%)$. In group $C$ the index increased from 1.86 to 2.21 at the end of the study. Inter-group comparison showed statistically significant differences $(p<0.05)$.

The findings of the present study are in agreement with the data in the literature, as other authors showed that ListerineÔ reduced plaque and gingivitis by 20-35 per cent and 25-35 per cent respectively, by disrupting cell walls and inhibiting bacterial enzymes, without disrupting the normal oral flora [12-14]. Phenolic compounds exhibitantiinflammatory properties by inhibiting prostaglandin synthetase, an enzyme involved in the formation of prostaglandins, which are primary inflammatory mediators [15].

Spearman correlation analysis showed significant correlations $(p<0.05)$ between the use of mouthrinses and the salivary and clinical parameters examined (table 5):

Table 5

CORRELATION ANALYSIS BETWEEN THE USE OF MOUTHRINSES AND THE SALIVARY AND CLINICAL PARAMETERS

\begin{tabular}{|c|c|c|}
\hline Variable & $p$ & Spearman coefficient \\
\hline Salivary pH & 0.006 & 0.528 \\
\hline Salivary flow rate & 0.011 & 0.321 \\
\hline Gingival Index & 0.000 & -0.826 \\
\hline Quigley-Hein Index & 0.000 & -0.792 \\
\hline
\end{tabular}

the salivary $\mathrm{pH}$ and flow rate increased, while the gingival index and plaque index decreased with the use of mouthrinses.

The differences found between the two mouthrinses used in increasing the salivary $\mathrm{pH}$ and reducing the plaque index may be explained by the more reduced antimicrobial effect of fluoride, which is mainly exerted on the cariogenic flora. Fluoride inhibits glycolysis of oral microorganisms by interfering with enolase enzyme and by blocking oxygenation of metabolic cycle for energy supply and reproduction and stabilizes oral eco-system. Moreover, accumulated fluoride in plaque by application of sodium fluoride mouthrinse can interfere with the metabolism of bacterial dental plaque [16-18]. Similar results in what concerns the effect of sodium fluoride mouthrinse on salivary $\mathrm{pH}$ were found in other studies, too $[7,19,20]$.

As some essential oil mouthwashes have a pH below 5.5 there is some concern they may cause tooth erosion [21]. Although the Listerine used in this study has a $\mathrm{pH}$ of 4.35 [22], rinsing with this mouthwash actually significantly raised salivary $\mathrm{pH}$ levels at the measured times postrinsing, and salivary $\mathrm{pH}$ remained above baseline values. Other authors have suggested that stimulation of salivary flow provides an increase in calcium and phosphate concentrations as well as the alkaline environment. Acidic mouth rinses may trigger the same mechanism, stimulating salivary flow and producing a rise in $\mathrm{pH}$ [2326].

\section{Conclusions}

The use of mouthrinses significantly increased salivary $\mathrm{pH}$ and flow rate of the young adults included in the study. In addition, ListerineO significantly decreased Gingival Index and Quigley-Hein Plaque Index after six weeks of daily use.

\section{References}

1.WALSH, L.J., Aust. Dent. J ., 45, no. 2, 2000, p. 76.

2.STOLERIU, S., GHIORGHE, C.A., POPA, C., STELEA, C., STEFANESCU, O., IOVAN, G., Romanian Journal of Oral Rehabilitation, 9, no. 2, 2017, p. 37. 
3.SOHAM, B., SRILATHA, K.T., SEEMA, D., J. Oral. Hyg. Health, 3, no. 6 , 2015, p. 192.

4.MURARIU, A., VASLUIANU, R., MATRICALA, L., STOICA, I., FORNA, N.C., Rev. Chim. (Bucharest), 67, no. 10, 2016, p. 2103.

5.LOKE , C., LEE, J., SANDER, S., MEI, L., FARELLA, M., J. Oral. Rehabil., 43, 2016, p.778.

6.PARASHAR, A., Sch. J. Dent. Sci., 2, no. 2B, 2015, p. 186.

7.HAMBIRE, C.U., JAWADE, R., PATIL, A., WANI, V.R., KULKARNI, A.A., NEHETE, P.B., J. Int. Soc. Prev. Community Dent., 5, no. 3, 2015, p. 218. 8.FEIER, I., ONISEI, D., ONISEI, D., Medicine in evolution (Timisoara), XVI, no. 1, 2010, p. 79.

9.MURARIU, A., PRICOP, M., BOBU, L., GELETU, G., DANILA, V., BALAN, A., Romanian J ournal of Oral Rehabilitation, 8, no. 1, 2016, p. 65. 10.LÖE, H., J. Periodontol., 38, suppl., 1967, p. 610.

11.IRELAND, R.A., Dictionary of Dentistry, Oxford University Press, 2010.

12.ALSHEHRI, F.A., Saudi Dent. J., 30, 2018, p. 2.

13.CORTELLI, S.C., CORTELLI J R., HOLZHAUSEN, M., FRANCO, G.C.N., REBELO, R.Z. et al., J. Clin. Periodontol., 36, 2009, p. 333. 14.RAJU, R., DIVYA, A., RAJ ENDRAN, G., JOHN, J.R., Int. J. Community Med. Public Health, 4, no.5, 2017, p.1429.

15.DEPAOLA, L.G., SPOLARICH, A.E., J. Dent. Hyg., 81, no. 5, 2007, p. 1.

16.LATIMER, J ., MUNDAY, J.L., BUZZA, K.M., FORBES, S., SREENIVASAN, P.K. et al., B.M.C. Microbiology, 15, 2015, p. 169.
17.LUSSI, A., HELLWIG, E., KLIMEK, J., Schweiz Monatsschr Zahnmed, 122, 2012, p.1030.

18.FORNA, N., FEIER, R.D., DASCALU, C.G., Romanian J ournal of Oral Rehabilitation, 10, no. 2, 2018, p. 113.

19.HANGANU, S.C., ARMENCIA, A.O., MURARIU, A.M., MACOVEI, G., HANGANU, L.C., GRIGORAS, S., BOBU, L.I., Mat. Plast., 51, no. 4, 2014, p. 388.

20.MURARIU, A., AGOP FORNA, D., MANOLACHE, F., FORNA, N.C., Romanian Journal of Oral Rehabilitation, 9, no. 3, 2017, p. 48.

21.CLAFFEY, N., J. Clin. Periodont., 30, suppl. 5, 2003, p. 22.

22.BELARDINELLI, P.A., MORELATTO, R.A., BENAVIDEZ, T.E., BARUZZI, A.M., LOPEZ DE BLANC, S.A., Acta Odontol. Latinoam., 27, no. 2, 2014, p. 66.

23.TOLENTINO, E.S., CHINELLATO, L.E.M., TARZIA, O., J. Appl. Oral. Sci., 19, no. 2, 2011, p. 90.

24.DEHGHAN, M., TANTBIROJ N, D., KYMER-DAVIS, E., STEWART, C.W., ZHANG, Y.H., J. Investig. Clin. Dent., 8, no. 2, 2017, p. 10.

25.IORGA, M., POP, L., MURARU, I.D., ALWAN, S., IOAN, B.G., Romanian Journal of Oral Rehabilitation, 10, no. 3, 2018, p. 32.

26.PANCU, G., ANDRIAN, S., STOLERIU, S., GHIORGHE , A., NICA, I., TOPOLICEANU, C., MOLDOVANU, A., TOFAN, N., IOVAN, G., Romanian J ournal of Oral Rehabilitation, 9, no. 2, 2017, p. 9.

Manuscript received: 9.08 .2018 